\title{
Paul Debreczeny, 1932-2008
}

Paul Debreczeny, Alumni Distinguished Professor of Russian and Comparative Literature Emeritus at the University of North Carolina, Chapel Hill, died on 18 March 2008 at the age of 76 following a period of declining health. Born in Budapest, Paul received his undergraduate degree from Eôtvõs University. During the 1956 revolution, he emigrated to England, where he took a doctorate in Russian literature at the University of London. In 1960 he came to the United States, where he established the Department of Russian Literature at Tulane University. He joined the faculty of the University of North Carolina, Chapel Hill, in 1967, served as chairman of the Department of Slavic Languages and Literatures from 1974 to 1979 , and, in 1991, became the founding director of the Center for Slavic, Eurasian, and East European Studies. He retired in 1999.

Paul was a prolific scholar, whose research over five decades was informed by a refined literary and aesthetic sensibility and a knowledge of Russian and western literature that was both wide-ranging and intimate. Although he made his mark primarily as a Pushkinist, Paul published on virtually every other significant nineteenth-century Russian writer-Nikolai Gogol', Ivan Turgenev, Fedor Dostoevskii, Lev Tolstoi, Anton Chekhov-and he also explored the links between Russian literature and English, French, and American literary works. From the 1960s through the early 1980s he published a series of analytic articles and monographs in which classic nineteenth-century texts emerge in a fresh and revealing light - the Russian literary canon defamiliarized, as it were. Paul's magisterial study of Aleksandr Pushkin's prose fiction, The Other Pushkin: A Study of Alexander Pushkin's Prose Fiction (Stanford University Press, 1983; later translated into Russian as Bludnaia doch': Analiz khudozhestvennoi prozy Pushkina, 1995), assured his status as the preeninent American Pushkin scholar; had he done nothing more at this point, his reputation would have been secure. Yet it was characteristic of the scholar and the man (including, by the way, the outdoorsman) that he always chose the more strenuous path, and so he now ventured into areas that had previously engaged his interest but in which he had not yet published.

While much of Paul's early scholarship shows the influence of Russian formalism, beginning in the $1980 \mathrm{~s}$ his work incorporates new analytic perspectives, notably reader response theory and cultural studies. The culmination of this new direction was Social Functions of Literature: Alexander Pushkin and Russian Culture (Stanford University Press, 1997), a multifaceted exploration of the myth that grew up around the figure of Pushkin from the 1830s through the Soviet period. Paul's interest in nonverbal representational art and its complex relationship to literature is reflected in the volume he coedited with Roger Anderson, Russian Narrative and Visual Art: Varieties of Seeing (University of Kentucky Press, 1994), which includes his essay on impressionism in Chekhov. Paul's retirement years were largely devoted to studying the life and work of the nineteenth-century Russian painter Isaac Levitan. At the time of his death he had already completed and revised a manuscript that his colleagues expect will be published posthumously.

For all his accomplishments, Paul was a thoroughly modest and down-to-earth person, who had nothing but scorn for self-important academics. Unfailingly generous to colleagues and students, he always encouraged and supported their best efforts. His softspoken manner and wise counsel saw the University of North Carolina Slavic Department through difficult times, and his ready wit was a welcome leaven to our academic earnestness. His passing is a loss to the profession and to all those who were fortunate to enjoy his friendship.

LaWrence E. FeinberG,

Madeline G. Levine

University of North Carolina, Chapel Hill

May 2008 